\title{
Composition, Distribution, and Diversity of Benthic Macroinvertebrate from Creeks around Lagos Lagoon, Nigeria
}

\section{ONYENA, AP}

Department of Marine Environment and Pollution Control, Faculty of Marine Environmental Management, Nigeria Maritime University, Okerenkoko, Delta Sate, Nigeria.Email: amarachionyena@gmail.com

\begin{abstract}
Anthropogenic activities comprise a significant threat to ecosystem balance and biodiversity integrity. The most impacted groups of animals are macrobenthic fauna that live on, or bury within sediments. This study investigated the population of macrobenthic species from Abule Agege (Station A), Abule Eledu (Station B), and Ogbe (Station C) creeks adjoining Lagos Lagoon, Nigeria. The sediments containing the benthos were collected using a Van Veen grab between 0800 and 1100 hrs from June to November, 2016. Results showed a total of 374 organisms belonging to 13 genera, 13 families, 11 orders, 6 classes and 4 phyla. The phyla included Mollusca ( 238 species), Arthropoda (98 species), Annelida (36 species) and Chordata ( 2 species). Station A had 74 species, with the highest number (23 species) being recorded in the August and lowest number ( 3 species) in November. Station B had 220 species with 73 species sampled in September and 7 species in June. Station C had 80 species, with 25 species in June and the lowest in September (4 species). The Mollusc Tympanotonus fuscatus was the most dominant specie (40\%), followed by Pachymelania aurita $(21 \%)$ and Clibanarius africanus $(16 \%)$. The abundance of Chironomous sp at Ogbe creek presents a high contaminated creek. There was high richness index in the study months. This can be attributed to the kind of human stressors that occurred at the differnt sites. The macrobenthic community structure analysis of the species recorded low diversity and abundance in the study stations, which depicts an environmentally stressed ecosystem.
\end{abstract}

\section{DOI: https://dx.doi.org/10.4314/jasem.v23i5.14}

Copyright: Copyright $(2019$ Onyena. This is an open access article distributed under the Creative Commons Attribution License (CCL), which permits unrestricted use, distribution, and reproduction in any medium, provided the original work is properly cited.

Dates: Received: 29 April 2019; Revised: 16 May 2019; Accepted 19 May 2019

Keywords: Variations, Distribution, Species diversity, Macroinvertebarate fauna, Creeks

Macrobenthic invertebrates are useful bio-indicators providing a more accurate understanding of changing aquatic conditions than chemical and microbiological data, which at least give short-term fluctuations (Ravera, 2000; Ikomi et al., 2005). Macrobenthic fauna (insect larvae, annelids (leeches), oligochaetes (worms), crustaceans (crayfish and shrimp), molluscs (clams and mussels), and gastropods (snails) etc.) are organisms that inhabit the bottom substrates (e.g. sediments) of their habitats for at least part of their life cycle (Rosenberg and Resh 1993). They are visible to the naked eye and are retained by mesh sizes $\geq 500$ $\mu \mathrm{m}$. They are easy to monitor because they can be sampled quantitatively and also respond to man-made disturbances (Otway and Gray, 1996). Macrobenthic fauna are important in the aquatic ecosystem because they form part of the aquatic food chain and they are also used to assess water quality and as pollution indicators (APHA, AWWA and WEF, 1998). They constitute the link between the unavailable nutrients in detritus and useful protein materials in fish and shellfish. Their sedentary nature makes it possible for them to readily imbibe and accumulate any xenobiotic compounds and other stressors released into the water body (Chaphekar, 1991). Since, it is often difficult to directly monitor disease outbreak and spread, or even longevity in natural populations and even human communities, bio-indicators such as Macrobenthic fauna are often used as surrogates to ameliorate this problem (Post, 2006). Most benthic organisms feed on debris that settle on the bottom of the water and in turn serve as food for a wide range of fishes (Idowu and Ugwumba, 2005). They also accelerate the breakdown of decaying organic matter into simpler inorganic forms such as phosphates and nitrates (Gallep et al., 1978). Odiete (1999) stated that the most popular biological method in assessment of freshwater bodies receiving domestic and industrial wastewaters is the use of benthic macro-invertebrates. Their composition, abundance and distribution can be influenced by water quality (Imevbore, 1970; Haslam, 1990; APHA, WWA, WEF, 1992; Odiete, 1999). In the benthos, differentprocesses like feeding, nesting and burrowing are determined by different grades of sediment particles. Hence for aquatic organisms like the benthic macro fauna, the nature of the bottom is important to their ecology. Some of the adverse effects that effluents can have on the creeks include, the physicochemical quality of sediment becomes altered and the quality of water is generally lowered, the

Email: amarachionyena@gmail.com 
dissolved oxygen content of the receiving water become reduced. The biodegraded organic substances increase biological oxygen demand (BOD), while oxidizable organic and inorganic substances in the water increase chemical oxygen demand (COD), therefore, the self purification process in the water becomes overstretched. The toxic chemicals in the effluents tend to kill the aquatic organisms inherent in the water body.Creeks and lagoons in Lagos play an important role in the socio-economic life of the coastal inhabitants such as transportation, aesthetics and food supply. Due to the flow of water from creeks to lagoons, untreated industrial effluents, solid wastes, and municipal sewage discharged into aquatic systems tend to degrade the quality of bottom substrates (sediments) beyond the acceptable limits. Therefore, it is important to study the impact of these pollutants on macrobenthic fauna, by evaluating their community structure and investigating the spatio-temporal variations across the sample period. The aim of research is to determine the composition and diversity of macrobenthic fauna so as to indicate the current health status and aesthetic values of the study creeks.

\section{MATERIALS AND METHODS}

Study area: The Lagos lagoon around the University of Lagos axis has three important creeks adjoining it, they include Abule Agege with coordinates $3^{0} 24.024^{\prime} \mathrm{E}$ and $6^{0} 30.864^{\prime} \mathrm{N}$, Abule Eledu $\left(3^{0} 23.914^{\prime} \mathrm{E}\right.$ and $\left.6^{0} 31.413^{\prime} \mathrm{N}\right)$ and Ogbe $\left(3^{0} 23.527^{\prime} \mathrm{E}\right.$ and $\left.6^{0} 30.627^{\prime} \mathrm{N}\right)$ creeks respectively. The research was carried out at these creeks (Plate 1).

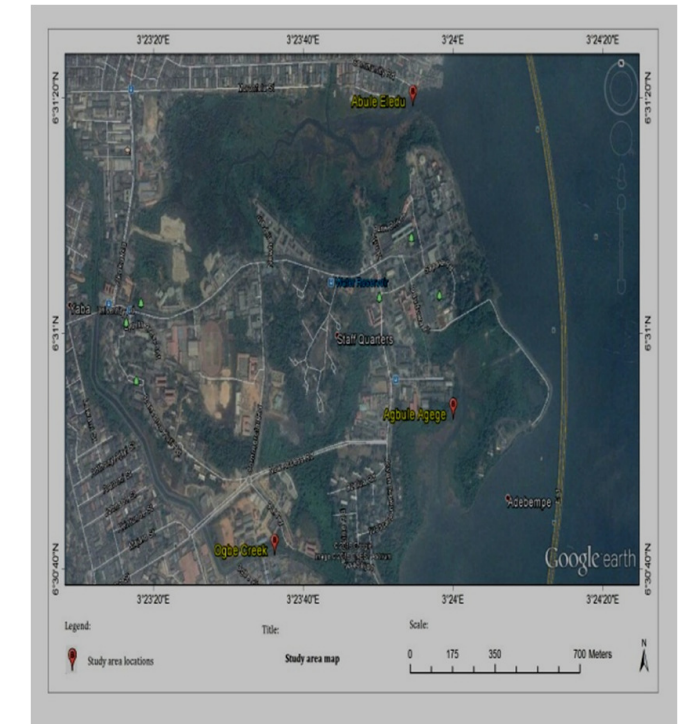

Plate 1: The aerial map of study areas showing their locations and their link to the Lagos lagoon
Station A: Station A is Abule Agege creek. It is located on the North-Eastern side of the University of Lagos. It comprises basically of brackish water which is usually shallow, tidal and sheltered. The creek is influenced by the tidal variations of Lagos Lagoon. The bedrock is a typical clayey mud. Active holes of crab species, Uca tangeri and Sesarma hazardii on the ground were seen. Periopthalamus sp, Balanus pallius, Chthamalu ssp, and Gryhea gazer were also observed. The prevailing and distinguished riparian vegetation were Elaeis guineensis (oil palm) and shrubs such as Acrosticuum aureum, Ficus sp. and Alchornea cordifolia. Other flora found includes; Phonenix reclinata, Rhizophora racemosa, Avicenia nitida, Drepanocarpus lunatus and Cyperus articulates.

Station B:This is Abule Eledu creek which is located about $500 \mathrm{~m}$ from station $\mathrm{A}$ in a remote freshwater swamp. It is a part of a creeklet, which discharges into the Lagos Lagoon. The width of the creek is about 20 $\mathrm{m}$ and an average depth of about $0.5 \mathrm{~m}$. It is a typical muddy substratum. Human activities at this site were negligible and restricted to fishermen occasionally setting gill net, acdja and cane traps; although, there was an enormous dumpsite stationed close to the creek. The riparian vegetation observed consists of mangrove plants which include Rhizophora sp. and Avizennia sp.

Station C: Station C is located about $1 \mathrm{~km}$ from station A on a swampy creek called the Ogbe creek which flows South-West through the Lagos metropolis and University of Lagos before emptying into the lagoon. Ogbe creek is non tidal and experience flooding in the wet season as a result of surface runoff. The stream channel width is about $30 \mathrm{~m}$ with an average flow velocity of $0.5 \mathrm{cmS}^{-1}$ (Edokpayi and Ayorinde, 2009). It has a sandy mud substratum. The water at this station was stinking with a strong foul odour and usually has a black/dark colouration which was an initial indication of pollution. Echhornia crassipes (water hyacinth); floating aquatic vegetations were dominant. Other aquatic macrophytes seen include; Dryopteries sp. (Fern), Lemna paucicosta (Duckweed), Salvinia molesta (Kariba weed or aquatic fern). The creek receives various domestic and industrial effluents from heavily populated urban settlements along its route. Anthropogenic activities at the site were high and included automobile repair workshops and car wash stations. Open public toilets and bathrooms, direct defecation of inhabitants into the water body and channelling of sewage and other domestic waste into the creek were also observed. 
Collection and analysis of samples: Benthic samples were collected monthly from June, 2016 to November, 2016 at three different study areas (Plate 1) using a Van-veen grab (grab $3 \mathrm{~mm}$ plate (surface: $0.025 \mathrm{~m}^{2}$, volume: $3.14 \mathrm{~L}$ and penetration depth: $10 \mathrm{~cm}$ ), usually between 0800 and $1100 \mathrm{~h}$. For each sampling station, five (5) hauls were made by sending the grab down into the bottom. The sediments were filtered using a sieve $(0.5 \mathrm{~mm}$ mesh apperture) to collect the benthos and stored in plastic container. The organisms were poured into a white enamel tray, stained with Rose Benger Solution and sorted using forceps. They were sorted out into different groups and preserved in 5\% formalin. The samples were transported to the Benthic Ecology Laboratory in the Department of Marine Sciences, University of Lagos for analysis. The sorted macrobenthic fauna were identified to species level under a compound microscope with the key guide of Yankson and Kendall (2001), Olaniyan (1968), Hart (1994), Quigley (1977) and Schreider (1990) and counted.

Analysis of Data: After sorting, identification, and counting of the benthos, statistical analysis of the data collected were done using PAST statistical program to obtain the measures of species richness (D), species diversity $(\mathrm{H})$, species equitability $(\mathrm{J})$, and Dominance (C). The method adapted for species diversity was proposed by Andem et al. (2012).

Determination of Species Richness Index (d):The Margalef index (d) is a measure of species richness which is expressed as

$$
\mathbf{d}=\frac{\mathbf{S}-\mathbf{1}}{\operatorname{In} \mathbf{N}}
$$

Whered $=$ Margalef richness index or species diversity index; $\mathrm{S}=$ Number of species in the population; $\mathrm{N}=$ Total number of individuals in species

Determination of Shannon-Weiner Index $(H s)$ :Shannon and weavers index (Hs): is a species abundance and evenness. It was expressed as:

$$
\mathbf{H s}=\frac{\mathbf{N} \log \mathbf{N}-\left(\sum \mathbf{P} \mathbf{i} \log \mathbf{P i}\right)}{\mathbf{N}}
$$

Where Hs = Shannon-Weiner diversity iindex; $\Sigma=$ summation; $\mathrm{i}=$ count denoting $\mathrm{i}^{\text {th }}$ species ranging from 1 to $\mathrm{n} ; \mathrm{Pi}=$ proportion that the $\mathrm{i}^{\text {th }}$ species represent to the total number of individuals in the sampling space

Determination of Species Eveness (j):Species equitability or evenness (E) was determined by the equation

$$
\mathrm{j}=\frac{\mathrm{Hs}}{\log _{2} S}
$$

Where $\mathrm{j}=$ equitability index; $\mathrm{Hs}=$ Shannon-Weiner diversity iindex; $S=$ number of species in the population

Determination of Simpson's Dominance Index (C): Simpson's Diversity Index is a measure of biodiversity and it is expressed as:

$$
\mathbf{C}=\frac{\sum\left(\mathbf{n}_{1}\right) 2}{N}
$$

Where $\mathrm{n}_{1}=$ the number of individuals in the $\mathrm{i}^{\text {th }}$ species; $\mathrm{N}_{1}=$ the total number of individuals

Determination of Menhinick's Index (D):The Menhinick's Index (D) was calculated using the formula below

$$
\mathrm{D}=\frac{\mathrm{S}}{\mathrm{N}^{\mathbf{1 / 2}}}
$$

Where $\mathrm{S}=$ number of species in the population; $\mathrm{N}=$ the total number of individuals in species;

\section{RESULTS AND DISCUSSION}

A total of 374 macrobenthic organisms were collected. Four (4) phyla were identified which include; phylum Mollusca (238 species), phylum Arthropoda (98 species), phylum Annelida (36 species) and phylum Chordata (2 species). In the month of June, 2016; 48 species were collected, in July (33 species), August (73 species), September (89 species), October (65 species), and November (66 species) as shown in Table 1. Abule Eledu had a total number of macrobenthic fauna (220 species), Abule Agege recorded a total number of 74 macrobenthic fauna and Ogbe creek recorded 75 species. The highest and lowest occurrence of macrobenthic fauna for Abule Agege was recorded in August (23 species) and November ( 3 species) respectively, while in Abule Eledu it was 73 species in September and 7 species in June. For Ogbe creek, it recorded 25 species in June and 4 species in September respectively (Table 1).The differences in the species recorded in the different sample stations (figures 3 to 5) illustrates the different nature of substratum the creeks contain. While species sampled from Ogbe creek illustrated characteristics of a fresh water habitat with respect to the types of organisms which are known to inhabit a freshwater ecosystem, was in dissimilarities with Abule Agege and Abule Eledu creeks which exhibited resemblance in their types of macrobenthic fauna sampled. The percentage contribution of various phyla of macrofauna to the overall benthic community represented in Fig 1 showed that Mollusca (64\%) was the dominant phylum within the sampled creeks. Clibanarius africanus of phylum Arthropoda was the highest occurring macrofauna, while in phylum mollusca Tympanotonus fuscatus recorded the highest 
specie, other species e.g. Chironomous sp etc. were also counted. The species of phylum Annelida that was sampled were Lumbriculus variegates and Lumbricus terrestris.

Table 1: Result of benthic macrofauna analysis

\begin{tabular}{|c|c|c|c|c|c|c|c|c|c|c|c|c|c|c|c|c|c|c|}
\hline \multirow{2}{*}{ TAXA } & \multicolumn{3}{|c|}{ JUNE } & \multicolumn{3}{|c|}{ JULY } & \multicolumn{3}{|c|}{ AUGUST } & \multicolumn{3}{|c|}{ SEPTEMBER } & \multicolumn{3}{|c|}{ OCTOBER } & \multicolumn{3}{|c|}{ NOVEMBER } \\
\hline & $\mathbf{A}$ & B & $\mathbf{C}$ & $\mathbf{A}$ & B & $\mathbf{C}$ & $\mathbf{A}$ & B & $\mathbf{C}$ & $\mathbf{A}$ & $\mathbf{B}$ & $\mathbf{C}$ & $\mathbf{A}$ & B & $\mathbf{C}$ & $\mathbf{A}$ & $\mathbf{B}$ & $\mathbf{C}$ \\
\hline A. Phylum: Mollusca & & & & & & & & & & & & & & & & & & \\
\hline SPECIES Physa fontinalis & - & - & 3 & - & - & 1 & - & - & 1 & - & - & - & - & - & - & - & - & - \\
\hline SPECIES Tympanotonus fuscatus & 5 & 3 & - & 4 & 12 & - & 11 & 21 & - & 5 & 42 & - & 8 & 16 & - & 3 & 16 & - \\
\hline SPECIES: Pachymelania aurita & 3 & - & - & 2 & - & - & 5 & 5 & - & 4 & 18 & - & - & 11 & - & - & 32 & - \\
\hline $\begin{array}{l}\text { SPECIES Neritina glabrata } \\
\text { B. Phylum Arthropoda }\end{array}$ & 6 & - & - & - & - & - & - & - & - & 1 & - & - & - & - & - & - & - & - \\
\hline SPECIES Hydrophilus sp. & - & - & 4 & - & - & - & - & - & - & - & - & - & - & - & - & - & - & - \\
\hline SPECIES Gyrinus aeneolus & - & - & 2 & - & - & - & - & - & - & - & - & - & - & - & - & - & - & - \\
\hline SPECIES Belostoma lutarium & - & - & 2 & - & - & 2 & - & - & - & - & - & - & - & - & - & - & - & - \\
\hline SPECIES Chironomous sp. & - & - & 5 & - & - & 1 & - & - & 2 & - & - & 4 & - & - & 12 & - & - & 2 \\
\hline SPECIES Argyroneta aquatica & - & - & 1 & - & - & - & - & - & - & - & - & - & - & - & - & - & - & - \\
\hline $\begin{array}{l}\text { SPECIES Clibanarius africanus } \\
\text { C. Phylum Annelida }\end{array}$ & 2 & 4 & - & 3 & 3 & - & 7 & 12 & - & 2 & 13 & - & 3 & 5 & - & - & 7 & - \\
\hline SPECIES Lumbriculus variegates & - & - & 7 & - & - & 2 & - & - & 2 & - & - & - & - & - & 3 & - & - & 4 \\
\hline $\begin{array}{l}\text { SPECIES Lumbricus terrestris } \\
\text { D. Phylum Chordata }\end{array}$ & - & - & - & - & - & 2 & - & - & 7 & - & - & - & - & - & 7 & - & - & 2 \\
\hline SPECIES Gnatoiepis sp. & - & - & 1 & - & - & 1 & - & - & - & - & - & - & - & - & - & - & - & - \\
\hline
\end{tabular}

Table 2: Community structure of benthic macrofauna

\begin{tabular}{|c|c|c|c|c|c|c|c|c|c|c|c|c|c|c|c|c|c|}
\hline Parameters & $\pi \mathrm{NE}$ & & & $\pi L Y$ & & & $A U G$ & & SEPT & IEMBI & & OCI & TOBER & & & NOVE & BER \\
\hline & $\mathrm{A}$ & $\mathrm{B}$ & $\mathrm{C}$ & $\mathrm{A}$ & B & $\mathrm{C}$ & A & $\mathrm{B}$ & $A$ & $\mathrm{~B}$ & $\mathrm{C}$ & $A$ & $\mathrm{~B}$ & $\mathrm{C}$ & $A$ & B & C \\
\hline Taxa_S & $\begin{array}{r}4 \\
16\end{array}$ & 2 & 8 & 3 & 2 & 6 & 3 & $\begin{array}{rr}34 \\
38 & 12\end{array}$ & $\begin{array}{r}4 \\
12\end{array}$ & 3 & $\frac{1}{4}$ & 2 & 3 & 3 & 1 & 53 & 3 \\
\hline $\begin{array}{l}\text { Indivaduals } \\
\text { Dominance D }\end{array}$ & $\begin{array}{r}10 \\
0.28\end{array}$ & 0.51 & $\begin{array}{r}25 \\
0.13\end{array}$ & $\begin{array}{r}9 \\
0.35\end{array}$ & $\begin{array}{r}15 \\
0.68\end{array}$ & $\begin{array}{r}9 \\
0.18\end{array}$ & $\begin{array}{r}23 \\
0.36\end{array}$ & $\begin{array}{r}3812 \\
0.420 .4\end{array}$ & $\begin{array}{r}12 \\
0.31\end{array}$ & $\begin{array}{r}73 \\
0.42\end{array}$ & $\begin{array}{l}4 \\
1\end{array}$ & 0.603 & $\begin{array}{r}32 \\
0.392\end{array}$ & $\begin{array}{r}22 \\
0.41\end{array}$ & $\begin{array}{l}3 \\
1\end{array}$ & $\begin{array}{r}53 \\
0.43\end{array}$ & $\begin{array}{r}8 \\
0.37\end{array}$ \\
\hline Simpson_1- & 0.71 & 0.48 & 0.82 & 0.64 & 0.32 & 0.81 & 0.63 & 0.570 .5 & 0.68 & 0.57 & 0 & 0.396 & 0.607 & 0.58 & 0 & 0.56 & 0.62 \\
\hline Shannon_H & 1.30 & 0.68 & 1.88 & 1.06 & 0.50 & 1.73 & 1.04 & 0.951 .1 & 1.23 & 0.97 & 0 & 0.586 & 1.004 & 0.96 & 0 & 0.93 & 1.04 \\
\hline Evenness_e' & 0.92 & 0.98 & 0.82 & 0.96 & 0.82 & 0.94 & 0.94 & 0.860 .7 & 0.86 & 0.87 & 1 & 0.898 & 0.909 & 0.87 & 1 & 0.85 & 0.94 \\
\hline Menhinick & 1 & 0.75 & 1.6 & 1 & 0.51 & 2 & 0.62 & 0.481 .1 & 1.15 & 0.35 & 0.5 & 0.603 & 0.530 & 0.63 & 2.57 & 0.40 & 1.06 \\
\hline largalef & 1.08 & 0.51 & 2.17 & 0.91 & 0.36 & 2.27 & $0.6 ?$ & & 1.20 & 0.46 & 0 & & 0.577 & 0.64 & 0 & 0.49 & 0.96 \\
\hline Qquitability J & 0.9 & 0.9 & 0.9 & 0.9 & 0.7 & 0.9 & 0.95 & 0.870 .8 & 0.89 & 0.88 & 0 & 0.845 & 0.91 & 0.87 & & 0.85 & 0.94 \\
\hline
\end{tabular}

Key: $\boldsymbol{A}=$ AbuleAgege creek; $\boldsymbol{B}=$ AbuleEledu creek; $\boldsymbol{C}=$ Ogbe creek

Only 1 species, Gnatoiepis sp, was sampled for phylum Chordata. The percentage composition of the species diversity and species abundance of the benthic macrofauna at the three stations (Abule Agege creek (Station A), Abule Eledu Creek (Station B) and Ogbe Creek (Station C)), showed that species Tympanotonus fuscatus (40\%) (Fig. 2) was in abundance across the creeks within the sample period and is more dominant at Abule Agege and Abule Eledu creeks. Pachymelania aurita was the second most abundant species $(21 \%)$, followed by Clibanarius africanus (16\%) with other species occurring less than $10 \%$. Chironomous sp (24\%) was found to be dominant at Ogbe creek.

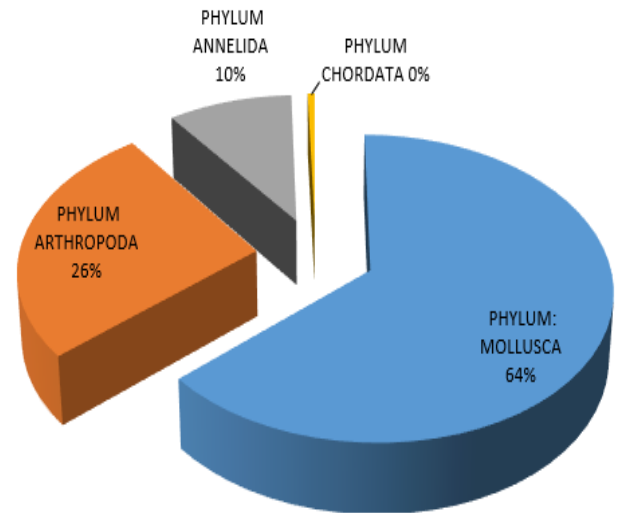

Fig 1: The Composition of the Benthic Macrofauna Phyla Sampled from the three Stations; Abule Agege creek (Station A), Abule Eledu creek (Station B) and Ogbe creek (Station C) 


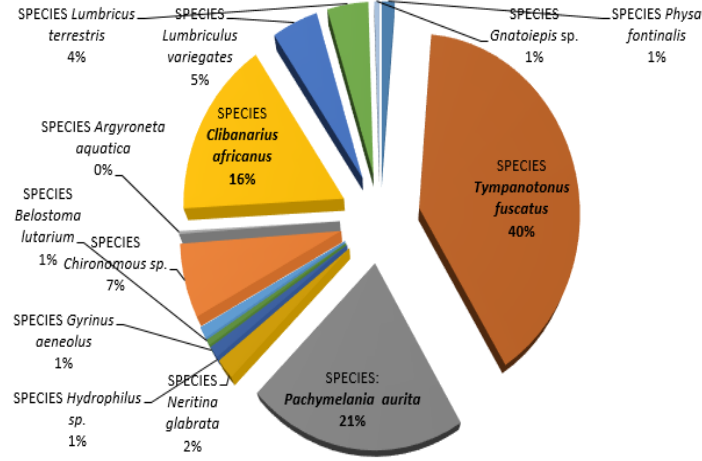

Fig 2: The overall percentage composition of the Species Diversity and Specie Abundance of the Benthic Macrofauna at the three Stations; Abule Agege creek (Station A), Abule Eledu Creek (Station B) and Ogbe Creek (Station C)

It was observed that there was low diversity of Physa fontinalis within the sampled creeks, coupled with the inconsistency in the distribution of Pachymelania auritaand Gnatoiepis sp. Also, Hydrophilus sp., Gyrinus aeneolus, Argyroneta aquatica recorded at Ogbe creek (freshwater habitat) was only found in the month of June, across the six months of research period; all these were attributed to changes in the ecology of the sediment and changes in biota due to some anthropogenic activities occurring at the site during the present study. The findings were synonymous to the reports given by Nkwoji et al.(2010), who laid emphasis on the low abundance of Neritina glabrata, thus attributing it to seasonal fluctuations and increasing human stressors.

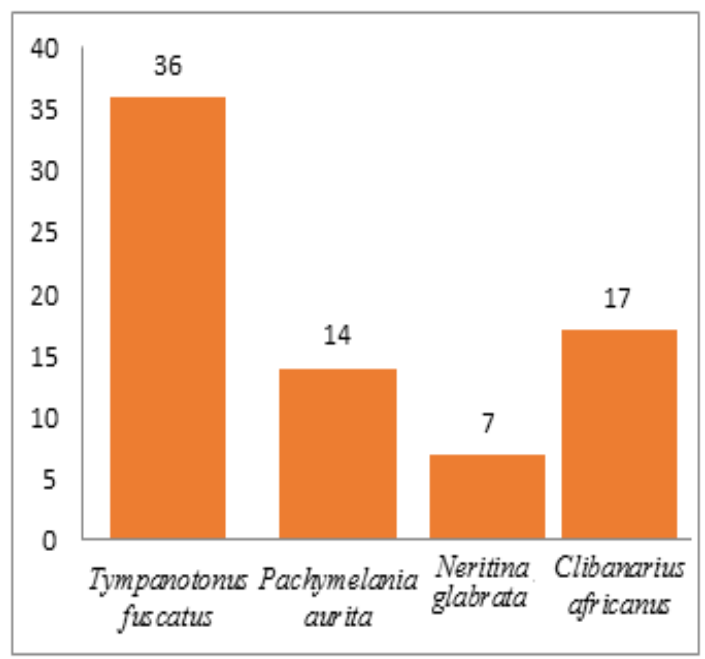

Fig 3: The Composition of Species Diversity and Species Abundance of Benthic Macrofauna at Abule Agege Creek
The abundance of Chironomous sp at Ogbe creek is an indication of a high level of contaminants present in the creek. This fact was clearly stated by Andem et al., (2012) who established the relationship between the presence of Chironomous larvae and human stressors (anthropogenic activities) in Ogbe creek.

Consequently, the overall diversity observed during the research was a product of all dynamic spatial and temporal changes that affected the community which is also a reflection of the extent to which the ecosystem has been perturbed by human activities. This very low diversity at the study stations was an indication of environmental disturbance. These were in agreement with the findings of Brown and Oyenekan (1998), Edokpayi and Ayorinde, (2009), Yakub and Ugwumba, (2009), Edokpayi et al., (2010), Nkwoji and Igbo (2010), Nkwoji et al., (2010), Yakub and Igbo, (2014), Ibezute et al., (2016).

The diversity indices showed low density and diversity of macrobenthic fauna for all the sample locations (Table 2). The low diversity and abundance recorded in this study was an attribute of the nature of the substratum (sediments) of the stations. This study affirmed the research carried out by Brown and Oyenakan (1998), Edokpayi and Nkwoji (2007), Nkwoji and Edokpayi (2013),on the species diversity and water composition.

The present study showed that Tympanotonus fuscatus was the most abundant species in Abule Agege and Abule Eledu creeks, while Chironomous sp was found to be dominant at Ogbe creek. This was in agreement with the research findings of Edokpayi et al., (2010), who reported that Chironomid larvae and the Nadid worms were the most abundant macrobenthic faunas within these creeks from previous studies conducted. The species abundance was slightly greater than what was previously observed by these researchers with a total of 374 organisms belonging to 57 benthic taxa, 13 genera, 13 families, 11 orders and 4 phyla compared to 246 organisms belonging to 16 benthic taxa, 13 genera, 12 families, 8 orders and 4 phyla as previously reported. 


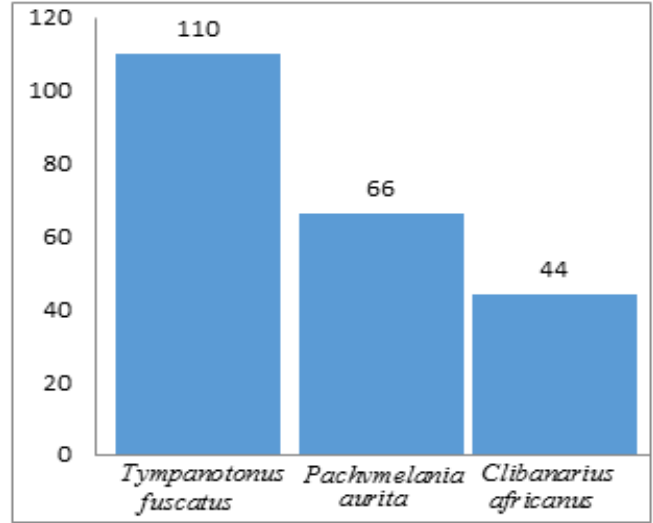

Fig 4:The Composition of species diversity and species abundance of benthicmacrofauna at Abule Eledu creek

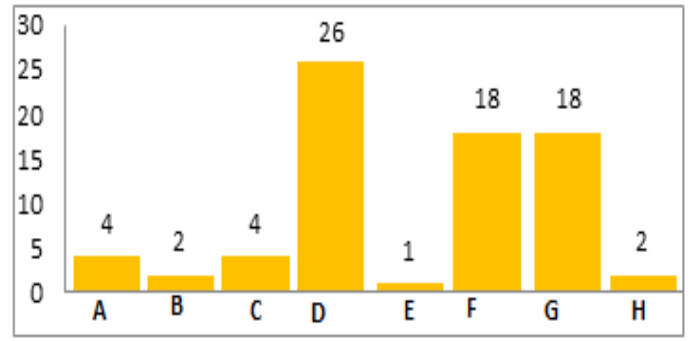

$A=$ Hydrophilus sp., $B=$ Gyrinus aeneolus, $C=$ Belostoma lutarium; $D=$ Chironomousspp; $E=$ Argyroneta aquatica; $F=$ Lumbriculus variegates $G=$ Lumbricus terrestris; $H=$ Gnatolepis sp.

Fig 5: The Composition of species diversity and species abundance of benthic macrofauna at Ogbe creek

The diversity of the macrobenthic fauna estimated by Margalef, Shannon-Wiener, Simpson's Dominance and Equitability indexes in the study locations were generally low and compared with the studies of Nkwoji et al., (2010) who reported low values in Margalef species richness and Shannon-Wiener diversity indexes. Species abundance was highest in the month June from Ogbe creek and least in the same creek by September. The number of individuals sampled was highest in September at Abule Eledu but least in Ogbe Creek in November. Biodiversity sampled was recorded highest at Ogbe creek in June however the creek recorded no biodiversity in the month of September. There was no community diversity in Abule Agege in November. This could be attributed to the fact that these stations experienced relatively high anthropogenic influence compared to other stations across the months, since suspended silt has the ability to reduce light penetration and primary productivity. Hence, resulting in the smothering of the aquatic fauna (Edokpayi and Nkwoji, 2007).
There was high richness index in the study months. The occurrence of higher taxa and individuals in Abule Agege creek and Abule Eledu creekis an indication of a lower degree of anthropogenic activities at these study stations compared to Ogbe creek. The low species abundance recorded in almost all the sample locations across the months are attributable to increase in influx of domestic sewage, garbage, open laundry, bathing, defecating, artisanal fishing activities, among others occurring at the sample locations. Hence, the overall Macrobenthic diversity within the locations of study was relatively low which depicts an environmentally stressed ecosystem.

Conclusion:The low diversity of macrobenthic fauna in the sampled creeks was an indication of the presence of high level of pollutants in the water bodies. The high level of human activities within the creeks accounted for the changes in the species and community diversity of the benthic fauna notable as bio-indicators of pollution. Environmental protective measures and appropriate knowledge are needed to alleviate human stressors within these creeks.

Acknowledgement:The author acknowledges other Researchers and Technologists of Benthic Ecology Laboratory, Department of Marine Sciences, University of Lagos for their support. The author is also particularly grateful to Prof. C. A. Edokpayi and Dr. J. A. Nkwoji for their expertise contribution.

\section{REFERENCES}

American Public Health Association, American Water Works Association and Water Environment Federation (APHA, AWWA and WEF) (1998). Standard Methods for the Examination of Water and Wastewater. 20th Edition, APHA, AWWA and WEF, Washington DC, 112-113.

Andem, AB; Okoroafor, KA; Udofia, U; Okete, JA; Ugwumba, AA (2012). The Composition, Distribution and Diversity of Benthic Macroinvertebrateof Ona River, Southwest Nigeria.Euro. J. Zoolog. Res. 1(2): 47-53.

APHA; AWWA; WEF (1992). Standard Methods for the Examination of Water and Wastewater. American Public Health Association, Greenberg, A.E., Clesceri, L.S., and Eaton, A.D., (eds) 18th Edition. 120-123.

Brown, CA;Oyenekan, JA (1998). Temporal variability in the structure of Lagos lagoon and harbour. Nig. Pollut.Arck hydro. 45(1): 45-54.

Chaphekar, SB (1991). An overview on bio-indicators. $J$. Environ. Bio.12: 163-168. 
Edokpayi, CA; Olowoporoku, AO; Uwadiae, RE (2010). The hydrochemistry and macrobenthic fauna characteristics of an urban draining creek. Internat. J. Biodiver.Conserv.2(8): 196-203.

Edokpayi, CA;Ayorinde, AO;(2009). Physical, Chemical and Macrobenthic Invertebrate Fauna Characteristics of Swampy Water Bodies within University of Lagos, Nigeria. MSc.Dissertation, Department of Marine Sciences, Faculty of Science, University of Lagos, Nigeria. 9pp.

Edokpayi, CA;Nkwoji, JA (2007). Annual changes in the physicochemical and macrobenthic invertebrate characteristics of the Lagos lagoon sewage dump site at Iddo, Southern Nigeria. Ecol. Environ. Conserv. 13(1): $13-17$.

Eruola, AO; Ufoegbune, GC; Adeofun, CO; Idowu, OA; Abhulimen, SI (2011). An assessment of the effect of industrial pollution on Ibese River, Lagos, Nigeria. Afri. J. Environ. Sci. Techno.5(8): 608-615.

Gallep, GW;Kitchell, JF; Bartell, SM(1978). Phosphorus release from Lake Sediments as affected by chironomid. Ver inter vere for Limnolo. 20: 458-465.

Haslam, SM(1990). River Pollution: An Ecological Perspective. Belhaven Press, Belgium. 253pp.

Ibezute, AC; Asibor, GI;Ibezute, SU (2016). Ecological Assessment of Brewery Effluent Impact on the Macrobenthic Invertebrates of Ikpobia River, Edo State Nigeria. Internat. J.Ecosys. 6(3): 47-54.

Idowu, EO; Ugwumba, AA (2005). Physical, chemical and benthic faunal characteristics of a Southern Nigeria Reservoir. The Zoolog.. 3: 15-25.

Ikomi, RB;Arimoro, FO; Odihirin, OK(2005). Composition, distribution and abundance of macroinvertebrates of the Upper Reaches of River Ethiope Delta State, Nigeria. The Zoolog. 3: 68-81.

Imevbore, AMA;Bakare, O (1970). The food and feeding habits of non-cichlid fishes of the River Niger in the Kainji Reservoir area. In: Kainji: a Nigerian manmade lake. Kainji Lake studies, Ecology. Visser S. A. (ed), Ibadan, Nig.Institu. Soc. Eco. Res.1: 49-64.

Nkwoji, JA; Yakub, A; Ajani, GE; Balogun, KJ; Renner, KO; Igbo, JK; Ariyo, AA; Bello, BO(2010). Seasonal Variations in the Water Chemistry and Benthic Macroinvertebrates of a South Western Lagoon, Lagos, Nigeria. J.Americ. Sci. 6(3): 85-92.

Nkwoji, JA; Edokpayi, CA(2013). Hydrochemistry and community structure of benthic macroinvertebrates of a south western Lagoon, Lagos, Nigeria. Res.J. Pharm. Chem. Sci. 4(1): 1119 - 1131.
Nkwoji, JA; Igbo, JK (2010). A comparative study of Benthicmacroinvertebrates in the Eastern and Western parts of Lagos lagoon Nigeria. Environ. Res. J. 4(2): 152-186.

Odiete, WO(1999). Environmental physiology of animals and pollution. Diversified Resources, Lagos, Nigeria. 26pp.

Otway, NM; Gray, CA(1996).Assessing the impacts of deepwateroutfalls on spatially and temporally variable marine communities. Mar.Environ. Res. Oxford.41:45-71.

Post, AL(2006). Physical surrogates for Benthic organisms in the Southern Gulf of Carpentaria, Australia: Testing and Application to the Northern planning area. Geoscience Australia, Canberra. 6pp.

Quigley, M(1977). "Invertebrates of Streams and Rivers: A key to Identification". Edward Arnold Pub. UK. $84 \mathrm{pp}$.

Ravera, O(2000). Ecological monitoring for water body management. Proceedings of Monitoring Tailormade III. International Workshop on Information for Sustainable Water Management. 157-167pp.

Rosenberg, DM; Resh, VH (1993). Freshwater biomonitoring and benthic macroinvertebrates. Chapman and Hall. 488pp.

Schreider, W (1990). Field Guide to the commercial Marine Resources of the Gulf of Guinea. Food and Agriculture Organization, Rome. 268pp.

Yakub, AS; Igbo, JK (2014). Assessement of Benthic macro-invertebrate fauna of two contiguous coastal water bodies within barrier lagoon complex, western Nigeria. J. Environ. Hum. 1(2): 39-46.

Yakub, AS; Ugwumba, AA(2009). A study of macroinvertebrate fauna of lower OgunRiver at Ishasi, Ogun state, Southwestern Nigeria.Zoolog. 7: 65-74.

Yankson, K; Kendall, M (2001). A study guide to the Seashore of West Africa. Darwin Initiative Report 1. 132pp. 